\title{
Turning Atrocity Prevention Inside-Out: Community-Based Approaches to Preventing, Protecting, and Recovering from Mass Violence
}

Bridget Moix

Genocide Prevention Program, George Mason University

Follow this and additional works at: https://digitalcommons.usf.edu/gsp

\section{Recommended Citation}

Moix, Bridget (2016) "Turning Atrocity Prevention Inside-Out: Community-Based Approaches to Preventing, Protecting, and Recovering from Mass Violence," Genocide Studies and Prevention: An International Journal: Vol. 9: Iss. 3: 59-69.

DOI:

http://dx.doi.org/10.5038/1911-9933.9.3.1313

Available at: https://digitalcommons.usf.edu/gsp/vol9/iss3/7

This Articles is brought to you for free and open access by the Open Access Journals at Digital Commons @ University of South Florida. It has been accepted for inclusion in Genocide Studies and Prevention: An International Journal by an authorized editor of Digital Commons @ University of South Florida. For more information, please contact digitalcommons@usf.edu. 


\title{
Turning Atrocity Prevention Inside-Out: Community-Based Approaches to Preventing, Protecting, and Recovering from Mass Violence
}

\author{
Bridget Moix \\ Genocide Prevention Program, George Mason University \\ Fairfax, VA, USA
}

\begin{abstract}
This article reviews recent research and evolving practice of community-based approaches to preventing and mitigating mass violence. It considers growing evidence that externally driven international interventions in response to violence are failing due to a lack of recognition and support for local actors, and increasing research into locally-led efforts, such as community protection strategies, early warning and response systems, interreligious peacebuilding, and post-atrocity trauma healing. Drawing from examples from a wide range of cases, including Rwanda, Burundi, Democratic Republic of Congo, Central African Republic, Colombia, and Sri Lanka, the article identifies key lessons for improving atrocity prevention policy and practice. Based on examination of the literature and case studies, it argues for a fundamental shift in the field of atrocity prevention from external interventionism toward supporting local peace agency.
\end{abstract}

Keywords: atrocity prevention, local peacebuilding, community protection, agency, early warning, community-based

\section{Introduction}

Ten years after the adoption of the responsibility to protect doctrine by the global community in 2005, horrific images of mass violence against civilians in places like Syria and South Sudan continue to beam across our televisions and computer screens. Despite important progress over recent years in elevating genocide prevention as a policy priority and developing new tools for early warning and response, the persistence of large-scale, deliberate violence against civilians in far too many places around the world beckons for more effective approaches to protecting civilians and averting mass killing. While many within the international community argue for more robust peacekeeping, more rapid intervention, and more effective warning and risk systems, this article proposes shifting greater support toward peacebuilding actors and efforts within the local context where mass violence unfolds. My premise is that the growing recognition of the failures of international interventions to effectively halt violence and sustain peace alongside increasing evidence that local peacebuilding actors can play a positive role in helping to prevent violence and rebuild peace in more sustainable ways is relevant to the field of genocide prevention. ${ }^{1}$

As the peacebuilding field is increasingly demonstrating, and as anyone who has lived through a violent conflict situation understands, even amid the most wicked conflicts there are always individuals and communities resisting the systems of dehumanization and killing that allow genocide and mass atrocities to unfold. As documented on the web-based database Insight on Conflict (www.insightonconflict.org), local peacebuilding groups continue working in even the worst situations of violent conflict to foster dialogue and relationships across groups,

\footnotetext{
${ }^{1}$ Autesserre, Severine. 2010. The Trouble with Congo: Local Violence and the Failure of International Peacebuilding. Cambridge, UK: University of Cambridge; Autesserre, Séverine. 2014. Peaceland: Conflict Resolution and the Everyday Politics of International Intervention. Cambridge, UK: Cambridge University Press; Denskus, Tobias. 2007. "Peacebuilding Does Not Build Peace." Development in Practice, Vol. 7, No. 4-5, 656-662; Donais, Timothy. 2011. “Empoderamiento O Imposición? Dilemas Sobre La Apropiación Local En Los Procesos de Construcción de Paz Posconflictos Empowerment or Imposition? Dilemmas of Local Ownership in Post-Conflict Peacebuilding Processes." Relaciones Internacionales, February, No. 16; Funk, Nathan C. 2012. "Building on What's Already There: Valuing the Local in International Peacebuilding." International Journal, Vol 67, No. 2, 391-411; MacGinty, Roger, and Oliver P Richmond. 2013. "The Local Turn in Peace Building: A Critical Agenda for Peace." Third World Quarterly Vol. 34, No. 5, 763-783; Anderson, Mary B. and Marshall Wallace. 2013. Opting out of War: Strategies to Prevent Violent Conflict. Boulder; London: Lynne Rienner Publishers; Carpenter, Ami C. 2012. "Havens in a Firestorm: Perspectives from Baghdad on Resilience to Sectarian Violence." Civil Wars Vol. 14, No. 2, 182-204; MacGinty, Roger, and Palgrave Connect (Online service). 2011. International Peacebuilding and Local Resistance Hybrid Forms of Peace. New York: Palgrave Macmillan; MacGinty, Roger Mac. 2014. “Everyday Peace: Bottom-up and Local Agency in Conflict-Affected Societies." Security Dialogue Vol. 45, No. 6, 548-564; Kaplan, Oliver. 2013. "Protecting Civilians in Civil War: The Institution of the ATCC in Colombia." Journal of Peace Research Vol. 50, No. 3, 351-367; Richmond, Oliver. 2005. Transforming Peace (The Transformation of Peace and Conflict Studies). New York: Palgrave McMillan Publishers; Richmond, Oliver. 2011. A Post-Liberal Peace. New York: Routledege Publishers.
} 
protect civilians, prevent recruitment, promote tolerance and refute hate, and support healing and reconciliation in the face of inhumane acts. Faced with the seemingly binary choice of killing or being killed, these leaders and communities seek other options, and they are not alone in history. Though facing different types of violence in different contexts, many of these present day local peace agents are doing the work of genocide prevention on a daily basis. Their efforts, though newly documented, are not entirely new. Indeed, they may resemble the resisters who refused Nazi orders and protected their Jewish neighbors, the Colombian villagers who created peace zones to thwart attackers from all sides in a civil war, and the Rwandan Muslims who refused to be divided as Hutu-Tutsi during the genocide.

Traditionally, the genocide field has focused on mobilizing external interventions to halt mass violence once it is already underway. Recent efforts to shift the focus toward earlier prevention-arresting the processes that can lead to annihilative violence before the killing begins - represent an important shift in theory and approach. However, they remain bedeviled by the challenge of mobilizing attention and support from external international actors to situations that have not yet made the headlines. Closing the response gap may require turning the focus from external intervention toward internal capacity building and support for local actors, who inevitably experience the warning signs and escalating dynamics of mass violence before those watching from the outside. A growing body of research within the peacebuilding and conflict prevention fields is demonstrating that local communities facing the unraveling of their societies from atrocities, war, and violence can and do find creative, nonviolent, and effective methods for protecting their members, opting out of the violence, and restoring peace. ${ }^{2}$ These examples of what we can call local peace agency provide an important opportunity to the field of genocide prevention. They not only challenge our dominant assumptions about how mass violence can be averted, but may also help re-orient our theory and practice in ways that can help move upstream to earlier prevention, break repeating cycles of violence, and ensure more sustainable recovery and reconciliation processes over the long-term.

This article reviews some of the recent developments in theory, research, and practice around peacebuilding and the role of local peace actors, and considers what lessons they might offer the field of genocide prevention. It does not claim to examine all aspects of local violence and peacebuilding, address all realities faced in polarized societies, or consider the role of many important actors, such as diaspora and the displaced. In drawing lessons for the field of genocide prevention from local peacebuilding practice, I do not propose that all local actors are positive agents for helping to prevent genocide. Indeed local actors are also the perpetrators of atrocities and violence and societies at risk of mass atrocities deserve and should receive critical external support and intervention when needed. I do claim that the potential role of local peace agents as critical actors in genocide and atrocities prevention is too often overlooked and under-supported.

\section{Why Link Genocide Prevention and Peacebuilding?}

Although genocide and mass atrocities prevention, broader conflict prevention, and peacebuilding all draw from related theory and practice to help us better understand processes of human violence and halt, mitigate, or transform them, the three are often considered and treated within policy and practice as quite distinct fields. Each has worked to distinguish its own definitions and approaches to human violence, and each has advanced its own approaches through particular policy developments and practical initiatives. This specialization has important conceptual, theoretical, and practical benefits and is important as a still relatively new field of study works to define itself and deepen our understanding of the various forms of violent conflict that exist and the variety of approaches possible to seek a more peaceful world. It can, however, become a false distinction that reduces opportunities to learn and improve across different approaches. In fact, scholars and practitioners of genocide prevention, conflict prevention, and peacebuilding have a great deal to

\footnotetext{
${ }^{2}$ Anderson and Wallace, Opting out of War; Carpenter, "Havens in a Firestorm”, 182-204; Mac Ginty, "International Peacebuilding and Local Resistance"; MacGinty, "Everyday Peace: Bottom-up and Local Agency in Conflict-Affected Societies"; Kaplan, "Protecting Civilians in Civil War", 351-367; Richmond, Oliver. Transforming Peace (The Transformation of Peace and Conflict Studies); Richmond, Oliver. A Post-Liberal Peace.
} 
offer and learn from one another. By bringing together lessons from each across the current divide, we may all benefit in ways that help improve theory and, most importantly, strengthen our abilities to reduce various forms of tragic and preventable human suffering.

\section{A Paradigm Shift in the Making: From External Intervention to Local Leadership}

As the fields of conflict resolution, peacebuilding, and genocide prevention continue to grow, debate has risen around how the international community engages with local actors. Important flaws in current approaches are being revealed through case studies and evaluations of international peacekeeping and peacebuilding interventions, while scholars are beginning to challenge the assumption that the so-called international community, which is dominated by a relatively small group of countries and organizations, has either the right or the capacity to continually intervene in other countries in ways that are often not effective and may do further harm. ${ }^{3}$ Critics point to a liberal interventionist bias that dominates the field and assumes solutions to conflict need to be driven from the outside, represented largely by Western ideology and undertaken by actors and resources from the global North directed into the global South. ${ }^{4}$ As these critics explain, interventions designed and directed by external actors are too often superimposed upon local contexts for which they may not be appropriate, leading to failures to improve the peace, or worse, increased violence and injustice. ${ }^{5}$ As Nathan Funk points out, "Activities undertaken in the name of peacebuilding have often marginalized local actors, proceeded in ways that did not adequately respond to local expectations, and at times replaced one set of problems with another." ${ }^{6}$

In her in-depth case study of the UN's peace operation in the Democratic Republic of Congo from 2002-2006-an operation mobilized in response to one of the worst cases of mass violence against civilians in decades-Severine Autesserre points to a dominant peacebuilding culture embedded in the international system that ignores the importance of local violence and in turn marginalizes local peacebuilders. Her work reveals how the international community's focus on liberal peace (achieved largely through elections) and national and international issues (addressed at macro policy levels) ultimately failed to address the key drivers of violence (which were often local) and undermined much-needed local peacebuilding efforts (i.e., peace agency). ${ }^{7}$ Growing evidence demonstrates how failures to deliver peace through external interventions often derive from problems such as a lack of recognition or understanding of local knowledge and capacities; cookie-cutter technical solutions that do not fit specific contexts; and, the creation of parallel economies and systems of actors that undermine local capacities for peace. Contributing to these failures is an inadequate understanding of how people are already acting for peace in conflict contexts, why they are doing so, and what outside actors could do to support and expand their efforts.

Despite the reality that many of the most immediate choices between violence and peace are faced and made by those living within the immediate realities of violent conflict, those living outside these contexts continue to dominate the scholarship and resources directed toward peacebuilding. As the practice and study of peacebuilding begins to focus more attention on the local dynamics at play in national and regional conflicts, the importance of understanding local perspectives and potentials for peace is gaining ground. In his study of local peace committees and national peacebuilding, Andries Ondendaal argues for greater attention to strengthening local systems of resilience against violence as a critical and under-attended aspect of helping peace agreements

\footnotetext{
${ }^{3}$ Autesserre, The Trouble with Congo; Autesserre, Peaceland: Conflict Resolution and the Everyday Politics of International Intervention; Denskus, "Peacebuilding Does Not Build", 656-662.

${ }^{4}$ Jabri, Viviene. 2013. "Peacebuilding, the Local and the International: A Colonial or a Postcolonial Rationality?" Peacebuilding Vol. 1, No. 1, 3-16; Lidén, Kristoffer. 2013. "In Love with a Lie? On the Social and Political Preconditions for Global Peacebuilding Governance." Peacebuilding Vol. 1, No. 1, 73-90.

${ }^{5}$ Funk, “Building on What's Already”, 391-411; Donais, “¿Empoderamiento O Imposición?”; MacGinty, Roger Mac, and Oliver P. Richmond. 2013. “The Local Turn in Peace Building: A Critical Agenda for Peace." Third World Quarterly Vol. 34, No. 5, 763-83.

${ }^{6}$ Funk, "Building on What's Already", 392.

${ }^{7}$ Autesserre, Peaceland Conflict Resolution; Autesserre, The Trouble with Congo.
} 
stick at a national level. Doing so, however, requires understanding local conflict dynamics and capacities for peace, which are not merely "smaller clones of the master cleavage" in a society ${ }^{8}$ "Local dynamics and local agency, therefore, have an impact on the manner in which both violence and peace unfold." 9 Put more simply, as a colleague recently asked when I described the complicated, time-consuming, and expensive processes undertaken by large donors to determine what kinds of peacebuilding activities they should fund in a country: "Why don't they just ask the locals?"

This critique is not to suggest that the international community's efforts to halt violence and advance peace are not making notable contributions and improving the lives of many. The mere growth in number, scale, and variety of peacekeeping and peacebuilding interventions undertaken by the international community signals concerted effort aimed at strengthening the world's commitment, approaches, and tools to reducing human violence and preventing genocide and war. Research over recent years indicates that the international community is improving its ability to end wars through mediation and negotiated settlement, even if its ability to prevent new wars still lags behind.$^{10}$ The emergence of focused attention by the international community to strengthening tools for preventing mass atrocities and genocide is leading to new policies, analysis, and training. The UN Peacebuilding Commission has improved the way it operates and demonstrated important contributions in Liberia and Burundi. The non-governmental peacebuilding community has grown exponentially and now operates in conflict situations around the world providing analysis, training, mediation, facilitation, capacity-building and other direct and indirect support to high level peace processes as well as community-level peace programs. No doubt many lives have been saved and improved by the growing panoply of actors engaged and efforts underway.

Still, a growing body of research is demonstrating that despite theinvestment of billions of dollars in post-conflict, peacekeeping, and peacebuilding efforts by the international community, violent conflicts often re-emerge and root problems facing societies remain unresolved. Internationally designed and delivered interventions, while often critical to halt abuse or accompany a settlement, often become more a costly band-aid than a lasting solution, undermine or neglect local capacities, and may in fact replicate systems of injustice and violence that underlie the conflicts they purport to address. In turn, policymakers grow skeptical, cut budgets, and self-fulfilling prophecies of entrenched violence persist.

For 2014, the UN peacekeeping budget stood at $\$ 7.83$ billion, a cost that has been growing over the past two decades as the international community expands the number and size of its interventions to try to restore and rebuild peace in war-torn societies. This money represents significant savings compared to late reaction military interventions by unilateral countries like the United States, and the shift from blind neglect to active intervention is certainly a welcome advance in the international community's response to potential or outright genocide. However, current approaches require critical improvements if they are to become more effective at truly transforming societies impacted by mass violence and sustaining effective prevention for the longterm.

Turning genocide prevention inside-out to focus first on supporting and strengthening local capacities for peace within a society, linking them more effectively with regional and global backup response systems, would not only save lives, it would also be significantly less expensive and less damaging, and holds greater promise for finally closing the prevention gap so often debated.

\section{Community-Based Approaches to Atrocity Prevention}

In every situation of violence and human suffering, no matter how deep and seemingly entrenched, there are people working for peace. Some genocide scholars have documented such efforts by individual resisters or communities that refrained from violence, but we study these sparks of

\footnotetext{
${ }^{8}$ Odendaal, Andries. 2013. A Crucial Link: Local Peace Committees and National Peacebuilding. Washington, DC: United States Institute of Peace Press, 32.

${ }^{9}$ Odendaal, A Crucial Link, 17.

${ }^{10}$ Woocher, Lawrence. 2009. Preventing Violent Conflict: Assessing Progress, Meeting Challenges. Washington, DC: United States Institute of Peace.
} 
hope far too little. Peace practitioner scholars like Mary Anderson and John Paul Lederach have demonstrated how communities within situations of violent conflict can and often do find creative ways of avoiding harm or pro-actively advancing peace. Growing literature on zones of peace, infrastructures for peace, and other locally-led initiatives to create mechanisms for preventing and mitigating violence demonstrate the reality that this kind of agency for peace is alive and well in societies across the world today. ${ }^{11}$ Case studies from Colombia, Rwanda, Bosnia, Northern Ireland, South Africa, the Philippines, and elsewhere that illuminate some of the strategies communities employ - from engaging armed actors to mobilizing faith communities to employing nonviolent actions-provide further evidence that resisting violence and acting for peace is a common phenomena across cultures and geography, though its specific form and function may differ. In their recent work, Opting Out of War, Anderson and Wallace examine 14 such communities that chose not to engage in violence, and in some instances worked to actively restore or spread peace, within civil war contexts. They identify key characteristics across these cases-community cohesion, leadership, consultation, communication, and a willingness and ability to engage with armed groups - as common factors that may help communities opt out of violence. Notably, the study finds international involvement to have played little to no role in the choices these communities made to opt out of violence.

Anderson's book provides a critical jumping off point and inspiration for understanding how local initiatives by communities to avert violence might be relevant to atrocity prevention. The authors note:

The experiences of these nonwar communities remind us that oppositions exist. They remind us that capacities exist. They teach us that communities of people have the agency to shape things, even in the face of seemingly awful odds, to preserve the values they share and their ways of life. These lessons are not trivial. ${ }^{12}$

Other scholars like Oliver Kaplan of Denver University and Helen Berents of the University of Queensland are also building the evidence base for community-based violence prevention through particular case studies. Examining communities in Colombia and the Philippines that remained peaceful amid war, they again affirm that local actors can and do demonstrate agency, even within situations of severe violence and entrenched conflict, often without external support or intervention. ${ }^{13}$ In his research on how civilians survive violence, Casey Barrs finds local communities can and do employ a range of strategies to protect themselves without reliance on outside interveners. ${ }^{14}$ In her research on youth in Colombia, Berents finds that children demonstrate peace agency through the creative use of spaces available to them to make sense of the violence around them and foster a different, more constructive environment. These spaces in turn provide important arenas and resources for sustaining positive engagement and interaction across potential conflict lines a lesson directly relevant to atrocity prevention and a growing focus on providing youth constructive alternatives to help avoid recruitment and mobilization for violence. ${ }^{15}$

The voices and experiences of local peacebuilders in places that have experienced mass violence also hold insights for the international community's atrocity prevention agenda. In her book, This Light That Pushes Me: Stories of African Peacebuilders, Laura Shipler Chico profiles the personal experiences and photographs of nearly 40 individuals from across the continent who are actively working for peace amid or in the aftermath of war and genocide. ${ }^{16}$ This include individuals

\footnotetext{
${ }^{11}$ Mitchell, Christopher, and Hancock, Landon, editors. 2012. Local Peacebuilding and National Peace: Interaction between Grassroots and Elite Processes. New York: Continuum; Van Tongeren, Paul. 2013. "Potential Cornerstone of Infrastructures for Peace? How Local Peace Committees Can Make a Difference." Peacebuilding Vol. 1, No. 1, 39-60.

${ }^{12}$ Anderson and Wallace, Opting out of War, 176.

${ }^{13}$ Kaplan, Protecting Civilians in Civil War, 351-367.

${ }^{14}$ Barrs, Casey. 2010. How Civilians Survive Violence: A Preliminary Inventory. New York: The Cuny Center.

${ }^{15}$ Berents, Helen. 2014. "Its About Finding a Way: Children, Sites of Opportunity, and Building Everyday Peace in Colombia." International Journal of Children's Rights Vol. 22, 362-384.

${ }^{16}$ Shipler Chico, Laura. 2014. This Light That Pushes Me: Stories of African Peacebuilders. Richmond: Quaker Books.
} 
who survived, and sometimes participated in, mass violence in Rwanda, Burundi, the Democratic Republic of Congo (DRC), Sierra Leone, and Uganda, as well as peacebuilders from places like Tanzania and South Africa. Their reflections on their own experiences and their stories of resilience point to a diverse set of motivating factors behind their decisions to work for peace in the midst of violence. They include religious values (many are Quaker), transformational personal experiences (some were child soldiers or were saved by others), hope for a different future, and the influence and relationship with particular people in their families and communities. Understanding why and how individuals avoided being swept into violence, or rejected it later and chose instead to work for peace, can inform international policy and programming to better support such agents for change and strengthen local leaders who may be able to help interrupt or transform situations of potential mass violence.

As scholars of genocide and mass atrocities, we often assume that such local peace agents may be able to help a few people, but that their efforts will ultimately be overwhelmed by broader systematic organizing for violence, especially when high-level authorities are actively mobilizing toward mass killing. We point to the Nazis' ability to murder millions and occupy large swaths of territory as proof that individual resistance or community protection efforts will ultimately fail. But in fact, these efforts did save countless lives and created small points of light and resistance within a system of horrific violence. If they had been recognized, supported, strengthened, and backed up by the international community much earlier and in more effective ways, might they have succeeded in averting the genocide? Hattingh de Coning suggests conflicts are in fact so complex that they cannot be resolved without an approach that actively engages local leadership at the forefront. ${ }^{17}$ Systems theory is also teaching us to look at conflict as an interactive process where small change initiatives can grow and transform entire societies, if they gain enough power, reach enough other parts of the system, and become resilient against other forces at play. This is, in fact, how violence can take hold and spread. So, couldn't small initiatives for peace also do the same?

As scholars of genocide prevention, the question is at least worth posing, particularly given the growing recognition of the failures of current top-down approaches that rely on the international community coming in to save local communities. Moreover, as contributions from Critical Genocide Studies have pointed out, even interventions that focus on local empowerment, but do so simply as a linear process embedded within a larger view of societal progress as contingent upon concepts of Western democracy and liberal norms, ignore the dynamic cultural and political contexts through which genocide prevention efforts will ultimately have to navigate. ${ }^{18}$ This is not to suggest that local communities should be left to fend for themselves once violence is underway or if mass killing seems imminent. Local peacebuilding can be most effective upstream, before violence erupts, and in the aftermath and recovery to break cycles of violence. If mass atrocities are underway, external actors may need to intervene, but they should do so, to the greatest extent possible, in ways that reenforce local leadership for peace and strengthen local resilience against violence. Too often, rather than being at the center of analysis and action, they end up on the margins.

Community-based approaches to preventing mass violence are at work today in places around the world, from Syria to DRC to the Central African Republic. Understanding, documenting, and seeking to support them should be an imperative of our research and practice as a field. The non-governmental organization Peace Direct, working with local correspondents in over 35 countries, has identified and published through their Insight on Conflict website (www.insightonconflict.org) over 1000 local peacebuilding groups operating within conflict situations around the world. A collaboration of Burundian NGOs is establishing a local early warning/early response system in advance of potentially volatile elections. The Center for Peacebuilding and Reconciliation in Sri Lanka is working across interreligious lines to promote tolerance and reduce extremism. A former rebel soldier is now leading programs in North Kivu, DRC to convince combatants to give up their arms, working with communities to reintegrate them

\footnotetext{
${ }^{17}$ Hattingh de Coning, Cedric. 2012. "Complexity, Peacebuilding and Coherence: Implications of Complexity for the Peacebuilding Coherence Dilemma." Dissertation Paper, presented for defense to Stellenbosch University.

${ }^{18}$ Hinton, Alexander L. 2013. "Transitional Justice Time: Uncle Sam, Aunty Yan, and Outreach at the Khmer Rouge Tribunal" in Mass Atrocities in Asia: Legacies and Prevention. Edited by D. Mayersen and A. Pohlman. NY: Routledge, 82-94.
} 
and resist further violence. Healing and Rebuilding Our Communities, an initiative led by the Quaker Peace Network in Central and East Africa, is helping Muslims and Christians in the Central African Republic (CAR) overcome their trauma and recover their collective humanity. These are all locally-led initiatives, supported and accompanied by a variety of international actors in a variety of ways. They include different types of leadership, different theories of change, and different strategies. They rely on context-specific capacities first, and then seek additional resources and support where needed. They face different challenges and will yield different outcomes. But they offer some common lessons across their efforts. They represent both examples and opportunities of putting community-based approaches to atrocity prevention at the forefront of our collective efforts as a global community.

\section{Lessons for Atrocity Prevention Policy and Practice}

This growing debate suggests a fundamental flip-or paradigm shift-in our approach to addressing violent conflict, including the worst forms of mass atrocities and genocide, is needed. Increasing evidence that international interventions are enormously costly and questionably effective is pushing the international community to look first for solutions to conflicts within those communities most directly affected by the violence, an approach the international NGO Peace Direct calls local first. Taking such a community-based approach to preventing mass violence and genocide will require significant shifts in the dominant assumptions and paradigms that currently drive our theory and practice as a field, but they are well worth the effort. As growing research is showing, communities who are able to design, lead, and exercise their own approaches to prevent, respond, and recover from violence demonstrate remarkable creativity and innovation, heightened cultural and contextual sensitivity, greater cost-benefit ratios, and more sustainable and resilient impacts. While there may always be a need for external back-up response mechanisms, the current orientation of our resources, policies, and practices as an international community too often prioritizes external intervention over locally-led leadership. In doing so, we not only undermine the potential of preventive efforts that can respond to the earliest warning signs as they begin to emerge within societies, we also become mired in the practical and political challenges of trying to mobilize an external response after the crisis is already unfolding. We then bemoan the failure of the international community to respond quickly enough or with enough peacekeepers to effectively intervene in a situation that has escalated beyond control. This feeds the assumption that the failures are due to a lack of adequate intervening forces to confront and dispel perpetrators - a process which can itself escalate the violence and put more civilians and international actors at risk-rather than a recognition that the greatest potential for effective prevention and long-term transformative change resides within the societies themselves.

The genocide prevention field would do well to learn lessons from this growing debate in and the increasing number of community-based atrocity prevention approaches that are being documented, and apply them in transforming our own interventions toward a more local first approach. In doing so, we would begin to turn the paradigm and practice of genocide prevention inside-out, working first and foremost to help strengthen societies to resist, refute, and rebound from mass violence (an approach implied by the second pillar of the Responsibility to Protect doctrine), and bolstering international mechanisms to better accompany and strengthen local leadership to prevent the killing before it begins.

\section{Study What Works}

In his presidential address to the Peace Research Society in 2013, Pat Regan of Notre Dame urged greater research into the causes of peace, explaining that "unless we study the pathways to peace as vigorously as we study those to war, we might miss the forest because the trees are in our way", and reminding us that "the methods of achieving peace are probably not simply the negative of the pathways to war".$^{19}$ Thanks to decades of research and practice in the fields of conflict resolution, peace studies, and genocide prevention studies, we have developed a much deeper understanding

${ }^{19}$ Regan, Patrick M. 2014. “Bringing Peace Back in: Presidential Address to the Peace Science Society, 2013." Conflict Management and Peace Science Vol. 31, No. 4, 345. 
of the cycles and dynamics that drive systems of human violence and the horrific extents to which they can reach. We still know much less about the realities of human compassion, agency, and collective resistance that can and do interrupt and avert those systems, creating their own virtuous cycles within or alongside cycles of violence. If, as Elise and Kenneth Boulding often proposed, "what exists is possible," then understanding why and how people choose to actively pursue peace, particularly amid ongoing systems of potential or occurring mass violence, represents a critically understudied area of human possibility. ${ }^{20}$ Important efforts to document cases individuals and communities avoiding violence in the midst of mass violence are growing, but as a field we should dedicate much more research to this endeavor. We need to study what works among locally-led peacebuilding and atrocity prevention as much, if not more, as we study our failures as a human family. This will require dedicated researchers and resources, as well as the support and space within academic, policy, and practitioner organizations to engage in such inquiry, but it will be well worth the investments. Critically, this research needs to also include - from the design phase onward - those communities for whom it will be most relevant, local peacebuilders themselves. Collaborative, participatory, action research approaches offer important ways of ensuring our learning is not only grounded in the realities and perspectives of the communities we claim to support, but also serves as a contribution to their own learning.

We need to ask early and often: Who are the local peace agents at work in situations of conflict and potential mass violence? How do we recognize them? Why do they do what they do? What sustains them in taking risks to opt out of violence and actively protect and prevent? What kinds of support do they need to continue and strengthen their efforts? These questions should be at the forefront of our theory and practice, and should be accompanied by careful study, attentive listening, and collaborative action.

\section{Do No Harm}

Increasingly, we are learning that mass atrocities and genocidal violence are often cyclical, not linear, in nature, and are not bound by national borders. For example, current atrocities and violent conflict in Democratic Republic of Congo are directly connected to the legacies of genocide in Rwanda and cycles of violence across the region. In turn, the genocide in Rwanda was part of a history of violence and abuse dating back to colonialism. Trying to treat atrocities in only one moment of time ignores the need for a deeper understanding and seeking to address historical legacies of intergroup violence that often crosses borders and spans generations. Outsiders have difficulty fully grasping these legacies and their complex impacts on local societies. Without such understanding, interventions can end up harming rather than helping.

Just as the development community has embraced a Do No Harm approach, violence prevention and response efforts need to ensure first that they do not end up unintentionally fueling cycles of conflict and sparking unintended negative consequences. This means resisting the pressure to just "do something" in the face of a crisis and instead thoroughly analyzing the potential impacts of interventions and avoiding taking actions that contribute to legitimizing violence and fueling cycles of conflict. Military interventions in particular carry significant risks of negative spin offs, though diplomatic and development approaches can also end up undermining peace if not undertaken carefully.

Without grounding atrocities and violence prevention efforts in a broader understanding of the conflict and addressing root causes, even the best intentioned interventions aimed at halting one act of killing today may only end up contributing to new atrocities and violence tomorrow. The NATO intervention in Libya, for instance, opened the door to further civil violence in the country and the flow of more weapons in the region, fueling a new crisis in Mali. It also emboldened antiUS sentiment in the region and may have contributed to the attack on the US embassy and growing extremism in the region. Atrocities prevention programs and policies need to be prioritized as much in post-conflict and long-term preventive phases as in moments of intensifying violence, and atrocities prevention efforts need to be designed with local communities from start to finish.

${ }^{20}$ Portilla, Julian. 2006. “What Exists Is Possible: Stories from Conflict Resolution Professionals." Conflict Resolution Quarterly Vol. 24, No. 2, 241-248. 
The first guiding principle for decision-making and designing preventive actions should be Do No Harm, accompanied by a critical self-assessment to ensure policies and programs underway are not inadvertently contributing to the problem.

\section{Look Local First}

Effective atrocities prevention should, first and foremost, focus on supporting local communities to design and develop their own capacities and resiliencies to manage conflicts peacefully and justly, hold government and abusive actors accountable, resist manipulation and violence triggers, identify and respond to early warning signs of pending violence, and heal and reconcile from past atrocities.

As the "responsibility to protect" doctrine recognizes, building local community and government capacities to protect people from the threat of atrocities is preferable to relying on outside intervention after violence erupts. Efforts to create early warning systems remain constrained by a response gap - a lag in the time warning signs are identified and the time it takes for decision-making to happen. This gap grows the farther from the source of the threat decision-making is expected. Protection through intervention models also inevitably fall victim to geopolitics, a problem which may change shape over time but will persist for the foreseeable future. Local responses, if they can be effectively mobilized and supported, can help close the early warning gap and break out of the geopolitical struggle over intervention. Support and active response is needed from the international community when local mechanisms to prevent atrocities fail or are overwhelmed, but the ultimate goal should be building preventive systems at the local level that remove the need for outside intervention.

Currently, however, the atrocities movement remains dominated by the global North, with a major locus of activity at the UN and in the US, and focused on how countries outside a potential atrocity situation can intervene to halt violence once it erupts. Much less support is given to strengthening local capacities for peace that can be more effective at long-term prevention of violence. This imbalanced approach which overemphasizes external intervention without adequate support to building local peace capacities can actually disempower communities and reduce the potential for effective long-term prevention of deadly violence. Focusing the majority of attention on the question of external intervention, particularly military intervention, also inevitably raises political debates and reduces the space and resources available to improve local preventive capacities. Efforts to implement the responsibility to protect doctrine and genocide prevention at the international level need to be at least matched, if not surpassed, with a stronger focus of resources and support for strengthening local peace and violence prevention capacities-including community-based groups, civil society networks, and local and national governments.

We need to seek out and support the everyday peacebuilders who may be doing the most upstream work, long before warning signs have reached international policymakers and long-after the international community has moved on to the next crisis. In her work, Berents concludes that it is a type of "everyday peacebuilding" that is available and active among youth in Colombia. ${ }^{21}$ Such local peacebuilding is local not by geography but because, as Richmond and Mitchell argue, it belongs to the realm of everyday activity: "the local is the site of various forms of power, resources, and agency" that can be applied toward peace. ${ }^{22}$ This attention within the local peacebuilding literature to the role of ordinary actors choosing peace amid systems of violence is an important response to the post-liberal critiques of the field and its growing professionalization. As Roger MacGinty has argued, the concept and practice of everyday peace is a critical factor in how people navigate and survive within divided societies, especially in the face of failed international peace interventions. ${ }^{23}$

\footnotetext{
${ }^{21}$ Berents, "Its About Finding a Way", 362-384.

${ }^{22}$ Richmond, Oliver P, and Audra Mitchell. 2012. Hybrid Forms of Peace: From Everyday Agency to Post-Liberalism. New York: Palgrave Macmillan, 11.

${ }^{23}$ MacGinty, Roger Mac. 2014 "Everyday Peace: Bottom-up and Local Agency in Conflict-Affected Societies." Security Dialogue.Vol. 45, No. 6, 548-564. Available from https://www.escholar.manchester.ac.uk/uk-ac-man-scw:247104. (accessed December 2014).
} 
The more formalized the genocide prevention and peacebuilding fields becomes through organizational development, academic and scholarly programs, specialized training and consultant services, the more distant they risk becoming from the daily realities lived by most people experiencing the types of situations of entrenched violence and war that it aims to address, and the more reliant on external interventions as the right, or only, solution. A search for understanding and strengthening local peace agency offers one way of helping to ensure the ability to make peace is not lost to those experiencing the violence by an increasing technicalization of the field. If everyone has the choice to act for peace and exercise positive agency, then more people may feel empowered to access and act on that choice. Keeping peace within the ordinary and everyday realm of local communities can help strengthen motivations and means for peace agency. It also holds significant promise in building greater long-term resilience within societies against the risks of mass violence. The more peace becomes the responsibility of us all in our local communities, the less space potential perpetrators have to mobilize the scale of violence that we collectively abhor as a human family.

\section{Conclusion}

As the challenges (and failures) of linear, externally driven approaches to addressing conflict are increasingly evident, and more attention is given to locally-led approaches that support those actors in situations of conflict who are already working for peace, our field is ripe for a fundamental shift in paradigm and practice. Turning atrocity prevention "inside-out" to prioritize locally-led and community-based approaches may be a critical next step in our collective efforts to help avert the worst forms of human violence and reassert our common humanity.

\section{Bibliography}

Anderson, Mary B. and Marshall Wallace. 2013. Opting out of War: Strategies to Prevent Violent Conflict. London: Lynne Rienner Publishers.

Autesserre, Séverine. 2014. Peaceland: Conflict Resolution and the Everyday Politics of International Intervention. Cambridge, UK: Cambridge University Press. http://dx.doi.org/10.1017/ CBO9781107280366

Autesserre, Severine. 2010. The Trouble with Congo: Local Violence and the Failure of International Peacebuilding. Cambridge, UK: University of Cambridge. http://dx.doi.org/10.1017/ CBO9780511761034

Barrs, Casey. 2010. "How Civilians Survive Violence: A Preliminary Inventory." Published by The Cuny Center.

Berents, Helen. 2014. "'Its About Finding a Way': Children, Sites of Opportunity, and Building Everyday Peace in Colombia." International Journal of Children's Rights, Vol. 22, No. 2: pages 362-384. http://dx.doi.org/10.1163/15718182-02202006

Carpenter, Ami C. 2012. "Havens in a Firestorm: Perspectives from Baghdad on Resilience to Sectarian Violence." Civil Wars Vol. 14, No. 2, 182-204. http://dx.doi.org/10.1080/1369824 $\underline{9.2012 .679503}$

Chandler, David. 2013. "Peacebuilding and the Politics of Non-Linearity: Rethinking 'hidden' Agency and 'resistance."' Peacebuilding Vol. 1, No. 1: pages 17-32. http://dx.doi.org/10.108 $\underline{0 / 21647259.2013 .756256}$

Denskus, Tobias. 2007. "Peacebuilding Does Not Build Peace." Development in Practice, Vol. 7, No. 4-5: pages 656-662. http://dx.doi.org/10.1080/09614520701469906

Donais, Timothy. 2011. “¿Empoderamiento O Imposición? Dilemas Sobre La Apropiación Local En Los Procesos de Construcción de Paz Posconflictos Empowerment or Imposition?" Relaciones Internacionales, February, No. 16. Available from: http://www. relacionesinternacionales.info/ojs/article/view/268/233.html (accessed 5 May 2015).

Funk, Nathan C. 2012. "Building on What's Already There: Valuing the Local in International Peacebuilding." International Journal, Vol 67, No. 2: pages 391-411.

Hattingh de Coning, Cedric. 2012. "Complexity, Peacebuilding and Coherence: Implications of Complexity for the Peacebuilding Coherence Dilemma." Dissertation Paper, presented for defense to Stellenbosch University. 
Hinton, Alexander L. 2013. “Transitional Justice Time: Uncle Sam, Aunty Yan, and Outreach at the Khmer Rouge Tribunal" in Mass Atrocities in Asia: Legacies and Prevention. Edited by D. Mayersen and A. Pohlman, pages 82-94. New York: Routledge.

Jabri, Vivienne. 2013. "Peacebuilding, the Local and the International: A Colonial or a Postcolonial Rationality?" Peacebuilding Vol. 1, No. 1: pages 3-16. http://dx.doi.org/10.1080/21647259. 2013.756253

Kaplan, Oliver. 2013. "Protecting Civilians in Civil War: The Institution of the ATCC in Colombia." Journal of Peace Research Vol. 50, No. 3: pages 351-367. http://dx.doi. org/10.1177/0022343313477884

Lederach, John Paul. 1997. Building Peace: Sustainable Reconciliation in Divided Societies. Washington, D.C: United States Institute of Peace Press.

Lederach, John Paul. 2005. The Moral Imagination: The Art and Soul of Building Peace. New York: Oxford University Press.

Lidén, Kristoffer. 2013. "In Love with a Lie? On the Social and Political Preconditions for Global Peacebuilding Governance." Peacebuilding Vol. 1, No. 1: pages 73-90. http://dx.doi.org/10. 1080/21647259.2013.756273

MacGinty, Roger Mac. 2014. “Everyday Peace: Bottom-up and Local Agency in Conflict-Affected Societies." Security Dialogue Vol. 45, No. 6: pages 548-564. Available from https://www. escholar.manchester.ac.uk/uk-ac-man-scw: 247104. (accessed December 2014).

MacGinty, Roger, and Palgrave Connect (Online service). 2011. International Peacebuilding and Local Resistance Hybrid Forms of Peace. New York: Palgrave Macmillan. http://site.ebrary. com/id/10481693.

MacGinty, Roger, and Oliver P Richmond. 2013. "The Local Turn in Peace Building: A Critical Agenda for Peace." Third World Quarterly Vol. 34, No. 5: pages 763-783. http://dx.doi.org/ 10.1080/01436597.2013.800750

McGuiness, Kate. 2012. Local First: Development for the Twenty-First Century. London: Creative Space Independent Publishers.

Mitchell, Christopher, and Landon Hancock, editors. 2012. Local Peacebuilding and National Peace: Interaction between Grassroots and Elite Processes. New York: Continuum.

Odendaal, Andries. 2013. A Crucial Link: Local Peace Committees and National Peacebuilding. Washington DC: United States Institute of Peace Press.

Portilla, Julian. 2006. "What Exists Is Possible: Stories from Conflict Resolution Professionals." Conflict Resolution Quarterly Vol. 24, No. 2: pages 241-248. http://dx.doi.org/10.1002/crq.172

Regan, Patrick M. 2014. “Bringing Peace Back in: Presidential Address to the Peace Science Society, 2013." Conflict Management and Peace Science Vol. 31, No. 4: pages 345-56. http://dx.doi.org/10.1177/0738894214530852

Richmond, Oliver. 2011. A Post-Liberal Peace. New York: Routledege Publishers.

Richmond, Oliver. 2005. Transforming Peace (The Transformation of Peace and Conflict Studies). New York: Palgrave McMillan Publishers.

Richmond, Oliver P. 2012. "Beyond Local Ownership in the Architecture of International Peacebuilding." Ethnopolitics Vol. 11, No. 4: pages 354-375. http://dx.doi.org/10.1080/174 $\underline{49057.2012 .697650}$

Richmond, Oliver P, and Audra Mitchell. 2012. Hybrid Forms of Peace: From Everyday Agency to PostLiberalism. New York: Palgrave Macmillan.

Shipler Chico, Laura. 2014. This Light That Pushes Me: Stories of African Peacebuilders. Richmond, Indiana: Quaker Books.

Van Tongeren, Paul. 2013. "Potential Cornerstone of Infrastructures for Peace? How Local Peace Committees Can Make a Difference." Peacebuilding Vol. 1, No. 1: pages 39-60. http://dx.doi.org/10.1080/21647259.2013.756264

Woocher, Lawrence. 2009. Preventing Violent Conflict: Assessing Progress, Meeting Challenges. Washington, DC: United States Institute of Peace. 